\title{
$\gamma$-Glutamyl transferase activity in marine phytoplankton
}

\author{
Terry Ellen Thomas*, David H. Turpin** and Paul J. Harrison \\ Departments of Oceanography and Botany, The University of British Columbia, Vancouver, B. C. V6T 2B1, Canada
}

\begin{abstract}
The activity of the major ammonium assimilating enzyme glutamine synthetase was detected in marine phytoplankton by using the $\gamma$-glutamyl transferase assay. Transferase activity was observed in all cultures in both logarithmic and senescent growth phase for 15 species of marine phytoplankton from 8 algal classes. There was a large range in activities and no consistent differences appeared among the 8 classes. Phaeodactylum tricornutum and Dunaliella tertiolecta showed the lowest activities during logarithmic growth, while Eutreptiella gymnastica and Crystallolithus hyalinus exhibited lower activities during senescence. Nine out of the 15 species exhibited higher transferase activity during exponential growth than during senescence. However, in a few species such as Dunaliella tertiolecta and Skeletonema costatum, transferase activity increased several fold as the cells became senescent.
\end{abstract}

\section{INTRODUCTION}

For many years the main pathway of ammonium assimilation in plants was thought to be the reductive amination of $\alpha$-ketoglutarate catalyzed by the enzyme glutamate dehydrogenase (GDH: E.C. 1.4.1.3) (Basham and Kirk, 1964; Simms and Folks, 1964; Miflin and Lea, 1976). Recent studies on higher plants, bacteria and cyanobacteria suggest that ammonium is often assimilated via the glutamine synthetase (GS: EC. 6.3.1.2) pathway (Fowler et al., 1974; Miflin and Lea, 1976; Cook and Anthony, 1978; Pulman and Johnson, 1978) as described below:

$$
\text { glutamate }+\mathrm{NH}_{3}+\mathrm{ATP} \underset{\begin{array}{c}
\text { divalent } \\
\text { cation }
\end{array}}{\stackrel{\mathrm{GS}}{\longrightarrow}} \text { glutamine }+\mathrm{ADP}+\mathrm{Pi}
$$

This route appears most significant when external ammonium concentrations are low (Tempest et al., 1973; Betteridge and Ayling, 1976; Miflin and Lea, 1976; Arima and Kumazawa, 1977).

The relative importance of GS and GDH as nitrogen assimilating enzymes in marine phytoplankton has been investigated recently (Falkowski and Rivkin, 1976). From the relative $K_{m}$ values of $G S$ and $G D H$ in

\footnotetext{
- Addressee for reprint requests

- Present address: Dept. Biology, Queen's University, Kingston, Ontario K7L 3N6, Canada
}

the marine diatom, Skeletonema costatum, it was suggested that at normal extracellular nitrogen concentrations, GS was the primary enzyme of ammonium assimilation (Falkowski and Rivkin, 1976). An ammonium perturbation of an ammonium limited chemostat culture of Gymnodinium simplex resulted in an intracellular increase in glutamine with a corresponding decrease in glutamate over a very short time interval, suggesting an active glutamine synthetase pathway (Turpin and Harrison, 1978). Further evidence for the importance of the GS pathway has been obtained by monitoring the enzyme levels rather than the assimilation products (Edge and Ricketts, 1978). An ammonium perturbation of N-limited Platymonas striata caused a large increase in GS activity but had little or no effect on GDH (Edge and Ricketts, 1978). Ammonium grown cultures of Phaeodactylum tricornutum showed no GDH activity but an active GS/ GOGAT cycle (Somarajah and Holdsworth, 1981).

These investigations suggest that GS, rather than the previously suggested enzyme GDH, may be the major nitrogen assimilation enzyme in algae and higher plants. To date only a few marine phytoplankton species have been tested for GS activity (Falkowski and Rivkin, 1976; Edge and Ricketts, 1978; Paul and Cooksey, 1981). In the past the $\gamma$-glutamyl transferase activity has been used as an indication of GS activity. A direct correlation between $\gamma$-glutamyl transferase activity and the biosynthetic activity of GS in marine 
phytoplankton has recently been illustrated by Bressler and Ahmed (1984). A specific radiometric assay for GS also exists (Pahuja and Reid, 1982).

This study examines $\gamma$-glutamyl transferase activity in marine phytoplankton and the fluctuations in enzyme activity when the culture proceeds from exponential growth to senscence. Fifteen species of marine phytoplankton were tested from 8 algal classes.

\section{MATERLALS AND METHODS}

Cultures (Table 1) were obtained from the North East Pacific Culture Collection, Department of Oceanography, The University of British Columbia, Canada. Axenic cultures were grown in artificial seawater enriched with $\mathrm{f} / 2$, except that nitrate was omitted and replaced with $150 \mu \mathrm{M}$ ammonium (Guillard and Ryther, 1962; Davis et al., 1973). One-liter batch cultures were illuminated with cool-white fluorescent bulbs on a 16:8 L:D cycle and maintained at $15^{\circ} \mathrm{C}$. The irradiance was $60 \mu \mathrm{E} \mathrm{m} \mathrm{m}^{-2} \mathrm{~s}^{-1}$.

Cell numbers were determined using an inverted microscope after preserving the samples in Lugol's iodine solution. The growth of each culture was monitored frequently by measuring culture fluorescence with a Turner (Palo Alto, Calif. USA) Model 111 fluorometer.

These measurements were used to determine if the culture was in logarithmic or senscent phase of growth. $\gamma$-glutamyl transferase activity was assayed by measuring the formation of $\gamma$-glutamyl hydroxamate at $\mathrm{pH} 7.3$ with an imidazole - HC1 buffer (Shapiro and Stadtman, 1970) as described below:

$$
\text { L-glutamine }+\mathrm{NH}_{2} \mathrm{OH} \underset{\begin{array}{c}
\text { arsenate } \\
\text { or } \mathrm{Pi}
\end{array}}{\stackrel{\mathrm{ADP} \mathrm{Mn}^{2+}}{\longrightarrow}} \begin{array}{r}
\text { y-glutamyl hydroxamate } \\
+\mathrm{NH}_{3}
\end{array}
$$

The reaction mixture was as follows: Final Conc. $480 \mu$ l $1.0 \mathrm{M}$ imidazole buffer $\mathrm{pH} 7.3(\mathrm{NaOH})$

$\begin{array}{cc}300 \mu l 0.1 \mathrm{M} \text { glutamine pH } 7.3(\mathrm{NaOH}) & 0.48 \mathrm{M} \\ 30 \mu l 0.1 \mathrm{M} \mathrm{MnCl}_{2} & 0.03 \mathrm{M} \\ 40 \mu \mathrm{l} 0.01 \mathrm{M} \text { ADP pH } 7.3(\mathrm{NaOH}) & 3.0 \mathrm{mM} \\ 20 \mu \mathrm{l} 1.0 \mathrm{M} \text { potassium arsenate } \mathrm{pH} 7.3(\mathrm{KOH}) & 0.40 \mathrm{mM} \\ 30 \mu \mathrm{l} 2.0 \mathrm{M} \text { hydroxylamine } & 0.02 \mathrm{M} \\ & 0.06 \mathrm{M}\end{array}$

$100 \mu l$ crude enzyme extract

A crude enzyme extract was prepared by filtering approximately $600 \mathrm{ml}$ of culture onto a $47 \mathrm{~mm}$ glass fiber filter (Reeve Angel) at $190 \mathrm{~mm} \mathrm{Hg}$ negative pressure. The filter and cells were macerated by high speed homogenization in $1.5 \mathrm{ml}$ ice-cold imidazole buffer. The filter paper-buffer suspension was centrifuged at high speed on a clinical centrifuge for $5 \mathrm{~min}$ and the supernatant used as the crude enzyme extract.

Reaction mixtures were incubated at $37^{\circ} \mathrm{C}$ for $20 \mathrm{~min}$. A stop solution ( $1 \mathrm{ml}$ ) was used to terminate the reaction and develop color (Shapiro and Stadtman, 1970). The reaction tubes were centrifuged to remove any turbidity. The optical density of the solutions was measured at $540 \mathrm{~mm}$. Activities were expressed as $\mu$ moles $\gamma$-glutamyl hydroxamate formed per $10^{9}$ cells per hour or per $\mu \mathrm{g}$ chl a per hour, calibrated against a standard solution of $\gamma$-glutamyl hydroxamate. Replicate cultures were not used but six replicate analyses were done on each culture.

\section{RESULTS}

$\gamma$-glutamyl transferase activity in Skeletonema costatum was found to be linear with extract volume and with time. The optimum $\mathrm{pH}$ for this assay was determined to be 7.5 .

Significant $\gamma$-glutamyl transferase activity was found in all cultures (Table 1) in both logarithmic and senescent growth phases. There was a large range in relative activities and no consistent differences appeared among the 8 algal classes. Species which showed high activity during logarithmic growth were: Platymonas sp., Cryptomonas profunda and Hemiselmis rufescens. Low activity was exhibited by Phaeodactylum tricornutum and Dunaliella tertiolecta.

The ratios of activity in logarithmic and senescent phase growth are given in Table 1. All species showed equal or greater activities per $\mu \mathrm{l}$ chl a during logarithmic growth, except for Isochrysis galbana, Dunaliella tertiolecta, Skeletonema costatum and Brachiomonas submarina. The higher amount of chl a per cell in logarithmic phase is sufficient to account for their low $\log /$ senescence activity ratios (Table 1), except for $S$. costatum and $D$. tertiolecta.

\section{DISCUSSION}

The $\gamma$-glutamyl transferase assay for GS has been used extensively in studying activity in cell extracts primarily for 2 reasons: the colored final product $\gamma$-glutamyl hydroxamate is relatively stable and the transferase assay is generally 6 to 20 times more active than is the biosynthetic assay (Shapiro and Stadtman, 1970; Lee and Stewart, 1978). However, the physiological function of the transferase assay is not clear. The $\gamma$-glutamyl transferase reaction is not specific for GS and it is also catalyzed by several glutaminases and amidases (Meister, 1974). Rhodes et al. (1975) have 
Table 1. $\gamma$-glutamyl transferase activity (mmol $\gamma$-glutamyl hydroxamate $[\mu \mathrm{g} \mathrm{chl} \mathrm{a}]^{-1} \mathrm{~h}^{-1}$ ) in 15 species of marine phytoplankton from 8 algal classes, growing in logarithmic or senescent phase cultures. Each measurement is an average of 6 replicates with \pm one standard deviation. NEPCC $=$ North East Pacific Culture Collection

\begin{tabular}{|c|c|c|c|c|c|c|}
\hline \multirow{2}{*}{ Phytoplankton } & \multicolumn{4}{|c|}{$\begin{array}{c}\text { Activity } \\
\left.(\mathrm{mmo}][\mu \mathrm{g} \mathrm{ch}] a]^{-1} \mathrm{~h}^{-1}\right)\end{array}$} & \multicolumn{2}{|c|}{$\begin{array}{l}\text { Chlorophyll a } \\
\mu \mathrm{g}\left(10^{9} \text { cells }\right)^{-1}\end{array}$} \\
\hline & NEPCC \# & $\begin{array}{l}\text { Log Phase } \\
\text { (L) }\end{array}$ & $\begin{array}{l}\text { Senescent } \\
\text { phase (S) }\end{array}$ & $\begin{array}{l}\text { Activity } \\
\text { ratio L/S }\end{array}$ & $\mathrm{L}$ & $\mathrm{S}$ \\
\hline \multicolumn{7}{|l|}{ Bacilliariophyceae } \\
\hline Phaeodactylum tricornutum Bohlin & 31 & $0.12 \pm .02$ & $0.10 \pm .03$ & $1: 1$ & 66 & 40 \\
\hline Skeletonema costatum (Grev.) $\mathrm{Cl}$ & $18(\mathrm{c})$ & $0.22 \pm .06$ & $0.44 \pm .01$ & $1: 2$ & 150 & 140 \\
\hline Thalassiosira nordenskioeldii $\mathrm{Cl}$ & 252 (b) & $0.80 \pm .20$ & $0.61 \pm .05$ & $4: 3$ & 1800 & 2300 \\
\hline Thalassiosira pseudonana (Hust.) Hasle \& Heimdal & 58 & $0.84 \pm .06$ & $0.62 \pm .06$ & $3: 2$ & 82 & 140 \\
\hline \multicolumn{7}{|l|}{ Chlorophyceae } \\
\hline Brachiomonas submarina v. pulsifera Droop & 54 & $0.25 \pm .05$ & $0.41 \pm .01$ & $1: 2$ & 510 & 300 \\
\hline Dunaliella tertiolecta Butch. & 1 & $0.13 \pm .02$ & $0.66 \pm .07$ & $1: 5$ & 230 & 120 \\
\hline \multicolumn{7}{|l|}{ Chrysophyceae } \\
\hline Pseudopedinella pyriformis N. Carter & 49 & $0.50 \pm .03$ & $0.24 \pm .01$ & $2: 1$ & 360 & 390 \\
\hline \multicolumn{7}{|l|}{ Cryptophyceae } \\
\hline Cryptomonas profunda Butch. & 65 & $2.0 \pm .30$ & $0.60 \pm .10$ & $4: 1$ & 200 & 150 \\
\hline Hemiselmis rufescens Parke & 269 & $1.4 \pm .10$ & $1.6 \pm .07$ & $1: 1$ & 40 & 21 \\
\hline \multicolumn{7}{|l|}{ Dinophyceae } \\
\hline Amphidinium carterae Hulb. & 32 & $0.45 \pm .02$ & $0.32 \pm .08$ & $3: 2$ & 390 & 110 \\
\hline Prorocentrum minimum Schiller & 96 & $0.36 \pm .05$ & $0.20 \pm .10$ & $2: 1$ & 730 & 360 \\
\hline \multicolumn{7}{|l|}{ Euglenophyceae } \\
\hline Eutreptiella gymnastica Throndsen & $\mathrm{A} 2$ & $0.22 \pm .04$ & $0.05 \pm .02$ & $4 \cdot 1$ & 490 & 510 \\
\hline \multicolumn{7}{|l|}{ Prasinophyceae } \\
\hline Platymonas sp. & 84 & $1.4 \pm .07$ & $0.17 \pm .04$ & $9: 1$ & 140 & 280 \\
\hline \multicolumn{7}{|l|}{ Prymnesiophyceae } \\
\hline Crystallolithus hyalinus Gaarder \& Markali & 241 & $0.28 \pm .03$ & $0.046 \pm .004$ & $6: 1$ & 370 & 290 \\
\hline Isochrysis galbana Parke & 2 & $0.47 \pm .06$ & $0.91 \pm .02$ & $1: 2$ & 75 & 46 \\
\hline
\end{tabular}

shown a curvilinear quadratic relationship between total $\gamma$-glutamyl transferase activity and the synthetase activities in Lemna. Bressler and Ahmed (1984) have reported a good correlation between biosynthetic and transferase activity in marine phytoplankton. They surveyed 15 species from 6 classes.

The results of this study show large differences in $\gamma$-glutamyl transferase activity between species and between log and senescent phases. This suggests that glutamine synthetase is a key ammonium assimilating enzyme for some marine phytoplankton under certain nutritional conditions. This has also been confirmed by Bressler and Ahmed (1984). We found extremely low transferase activity in exponentially growing Dunaliella tertiolecta and Phaeodactylum tricornutum. Interestingly, these were the only 2 species that showed no biosynthetic activity in the study by Bressler and Ahmed (1984). Both studies show relatively high activity in Thalassiosira nordenskioeldii and T. pseudonana. A marked reduction occurred in some species such as Platymonas sp., indicating the importance of determining the stage of culture growth when enzyme activity is determined. There is no indication of higher activity in some algal classes than in others, however, the higher levels of activity detected in some species may have some ecological significance.
Several other studies indicate that GS activity was higher in cultures where the ammonium concentration in the medium was low (Tempest et al., 1973; Betteridge and Ayling, 1976; Falkowski and Rivkin, 1976; Arima and Kumazawa, 1977). The higher ratios of logarithmic to senescent phase $\gamma$-glutamyl transferase activity determined for 11 out of 15 species tested in this investigation suggest that this may only be true for a certain level of ammonium starvation. If the period of ammonium starvation is sufficient to force a culture into senescence it is possible that $\gamma$-glutamyl transferase levels as well as GS levels may decrease along with numerous metabolic processes.

Acknowledgements. We are grateful to Rosemary Waters for providing us with axenic cultures. This research was supported by the Natural Sciences and Engineering Research Council of Canada.

\section{LITERATURE CITED}

Arima, Y., Kumazawa, K. (1977). Evidence of ammonium assimilation via the glutamine synthetase-glutamate synthase system in rice seedling roots. Plant Cell Physiol. 18: $1121-1129$

Basham, J. A., Kirk, M. (1964). Photosynthesis of amino acids. Biochim. biophys. Acta 90: 553-562 
Betteridge, P. R., Ayling, P. D. (1976). The regulation of glutamine transport and glutamine synthetase in Salmonella typhimurium. J gen. Microbiol. 95: 324-334

Bressler, S. L., Ahmed, S. I. (1984). The detection of glutamine synthetase activity in marine phytoplankton: optimization of the biosynthetic assay. Mar. Ecol. Prog. Ser. 14: 207-217

Cook, R. J., Anthony, C. (1978). Regulation by glutamine of ammonia transport in Aspergillus nidulans. J. gen. Microbiol. 109: 275-286

Davis, C. O., Harrison, P. J., Dugdale, R. C. (1973). Continuous culture of marine diatoms under silicate limitation. I. Synchronized life cycle of Skeletonema costatum. J. Phycol. 9: 175-180

Edge, P. A., Ricketts, T. R. (1978). Studies on ammoniumassimilating enzymes of Platymonas striata Butcher (Prasinophyceae). Planta 138: 123-125 .

Falkowski, P. G., Rivkin, R. B. (1976). The role of glutamine synthetase in the incorporation of ammonium in Skeletonema costatum (Bacillariophyceae). J. Phycol. 12: $448-450$

Fowler, M. W., Jessup, W., Sarkissian, G. S. (1974). Glutamate synthase type activity in higher plants. FEBS Lett. 46: 340-342

Guillard, R. R. L., Ryther, J. H. (1962). Studies on marine diatoms. I. Cyclotella nana Hustedt and Detonula confervacea (Cleve) Gran. Can. J. Microbiol. 8: 229-239

Lee, J. A., Stewart, G. R. (1978). Ecological aspects of nitrogen assimilation. Adv. Bot. Res. 6: 1-43

Meister, A. (1974). Glutamine synthetase of mammals. In: Boyer, P. D. (ed.) The enzymes. Academic Press, New York, 10:699-754

Miflin, B. J., Lea, P. J. (1976). Review: the pathway of nitrogen assimilation in plants. Phytochemistry 15: 873-885
Pahuja, S. L., Reid, T W. (1982). Radioisotope assay for glutamine synthetase using thin-layer chromatography. J. Chromatogr. 235: 249-255

Paul, J. H., Cooksey, K. E. (1981). Regulation of asperaginase, glutamine synthetase, and glutamate dehydrogenase in response to medium nitrogen concentrations in a euryhaline Chlamydomonas species. Pl. Physiol. 68: 1346-1368

Pulman, D., Johnson, B. (1978). The enzymes of ammonia assimilation and their control in members of the genus Erwinia. J. gen. Microbiol. 106: 137-143

Rhodes, D., Rendon, G. A., Stewart, G. R. (1975). The control of glutamine synthetase level in Lemna minor L. Planta 125: 201-211

Shapiro, B. M., Stadtman, E. R. (1970). Glutamine synthase (Escherichia coli). Methods Enzymol. 17 A: 910-922

Simms, A. P., Folks, B. F. (1964). A kinetic study of the assimilation of ${ }^{15} \mathrm{~N}$-ammonia and the synthesis of amino acids in an exponentially growing culture of Candida utilis. Proc. R. Soc. London B 159: 479-502

Sornarajah, R., Holdsworth, E. S. (1981). Enzymes of importance in nitrogen assimilation in the diatom Phaeodactylum tricornutum. Australian Phytoplankton Workshop, p. 24

Tempest, D. W., Meers, J. L., Brown, C. M. (1973). Glutamate synthase (GOGAT): a key enzyme in the assimilation of ammonia by prokaryotic organisms. In: Prusiner, S., Stadtman, E. R. (ed.) The enzymes of glutamine metabolism. Academic Press, New York, p. 167-182

Turpin, D. H., Harrison, P. J. (1978). Fluctuations in free amino acid pools of Gymnodinium simplex (Dinophyceae) in response to ammonia perturbation: evidence for glutamine synthetase pathway. J. Physiol. 14: 461-464 